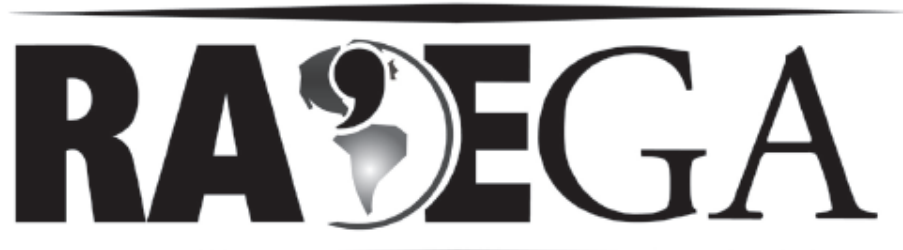

O ESPAÇO GEOGRÁFICO EM ANÁLISE

\title{
UNIDADES DE CONSERVAÇÃO EM ÁREAS URBANAS - O CASO DO PARQUE CINTURÃO VERDE DE CIANORTE - MÓDULO MANDHUY
}

\section{CONSERVATION UNITS IN URBAN SPACES - THE CASE OF CINTURÃO VERDE CITY PARK OF CIANORTE - MANDHUY MODULE.}

\author{
Nadir Leandro de SOUZA ${ }^{1}$
}

\section{RESUMO}

Com a finalidade de avaliar a relação dos frequentadores de espaços de preservação como unidades de conservação em espaço urbano, este trabalho usa como foco de análise a relação dos usuários do Módulo Mandhuy, parte constituinte do Parque Cinturão Verde de Cianorte/Paraná. Dessa forma realizou-se um estudo através de questionários aplicados a usuários do Módulo Mandhuy e subsídios teóricos que possam fundamentar a pesquisa no sentido de averiguar como o cidadão urbano muitas vezes privado de espaços públicos para lazer percebe e apropria-se de espaços onde o uso é limitado. Os resultados obtidos permitem afirmar que a relação entre usuários e área protegida em espaço urbano é conflitante tendo em vista o desconhecimento, por parte dos usuários, das finalidades de existência dessas áreas, que no momento da sua constituição não acomodou as necessidades das comunidades urbanas que as cercam.

Palavras-chave: unidades de conservação; conflitos de interesse em áreas preservadas; espaços públicos para lazer; áreas verdes urbanas.

\footnotetext{
${ }^{1}$ Mestre em Geografia e Doutoranda em Geografia - Departamento de Geografia-PGE - Universidade Estadual de Maringá. E-mail: nadirleandro@gmail.com
} 


\section{ABSTRACT}

In order to examine the relation of users of preservation sites as protected areas in urban space, this work as the focus of analysis is used the Mandhuy Module users list, which is part of the Cinturão Verde City Park of Cianorte-PR. Thus we carried out a study through questionnaires given to Module Mandhuy users and theoretical basis that justify the research in order to verify how urban citizens, often deprived of public spaces for recreation, realize and appropriate spaces in which use is limited. The results have revealed that the relation between users and the protected area in an urban space is conflictual, with a view to that part of users are unaware of the purpose of existence of these areas, which at the time of its constitution did not accommodate the needs of urban communities that surround it.

Keywords: Conservation units; conflicts of interest in conservation areas; public spaces for leisure; urban green areas.

\section{1 - INTRODUÇÃO}

As cidades constituem-se em locais de moradia, trabalho, sustento e reprodução da vida. E é nelas que atuam forças contraditórias entre os interesses coletivos da sociedade e a manutenção dos elementos naturais, resultando em desequilíbrio ambiental. Numa primeira perspectiva analítica, deve-se compreender o que seja o ambiental nas cidades. Costuma-se associar o ambiental apenas ao natural. Entretanto, o ambiental, principalmente nas cidades, também contempla o social. Como enfatiza Spósito (2003, p. 295) "[...] o ambiental não se restringe ao conjunto de dinâmicas e processos naturais, mas das relações entre estes e as dinâmicas e processos sociais".

Segundo Guzzo (2004, p. 2) "A urbanização em maior ou menor escala provoca alterações no ambiente das cidades. Essas alterações ocorrem no micro-clima e atmosfera das cidades, no ciclo hidrológico, no relevo, na vegetação e na fauna".

O espaço urbano requer planejamento que considere os elementos naturais, para que se possa nele inserir o mínimo necessário para qualificar a vida do cidadão e do meio ambiente das cidades. Loboda e De Angelis (2005, p. 131) observam que:

A qualidade de vida urbana está diretamente atrelada a vários fatores que estão reunidos na infra-estrutura, no desenvolvimento econômico-social e àqueles ligados à questão ambiental. No caso do 
ambiente, as áreas verdes públicas constituem-se elementos imprescindíveis para o bem estar da população, pois influenciam diretamente na saúde física e mental da população.

Um dos meios para se alcançar às melhorias necessárias no espaço urbano são as praças e os parques públicos, excelentes opções para oferecer espaços para recreação, sociabilidade e preservação ambiental. (LOBODA; DE ANGELIS, 2005).

Nesses espaços ocorre a presença de elementos naturais que, para Ribeiro (2003, p. 327), são recursos indispensáveis para prover a base natural da vida nas cidades. Frente a essa questão, o autor diferencia ambiente criado pela ação humana daquele que resulta dos processos naturais. "O primeiro é criação humana, mediado pelo trabalho, incorporando um intricado sistema de representação. O segundo resulta de processos naturais. Ou seja, o ambiente produzido está pautado nas representações imaginárias que varia segundo a diversidade de grupos sociais".

Assim, estão inseridas nas cidades, as áreas verdes urbanas que se apresentam sob diversas categorias, como os parques, as áreas livres, os espaços abertos, as praças, as unidades de conservação, entre outras categorias, e que são importantes para amenizar o desconforto produzido pelo aparato urbano.

As áreas verdes presentes em espaços urbanos, segundo Loboda (2003, p. 29), são,

[...] da mais alta importância para a qualidade da vida urbana. Ela age simultaneamente sobre o lado físico e mental do Homem, absorvendo ruídos, atenuando o calor do sol; no plano psicológico, atenua o sentimento de opressão do Homem com relação às grandes edificações; constitui-se em eficaz filtro das partículas sólidas em suspensão no ar, contribui para a formação e o aprimoramento do senso estético, entre tantos outros benefícios.

Algumas categorias de áreas verdes urbanas constituem-se em espaços de proteção ambiental, como é o caso de determinados parques inseridos em cidades, classificados como Unidades de Conservação, que pela Lei que instituiu o SNUC (Lei o 9.985, de 18 de julho de 2000) são classificadas de Proteção Integral, logo tem como principal objetivo à preservação dos seus componentes naturais (fauna e flora), além de possibilitar a realização de 
pesquisas científicas e o desenvolvimento de atividades de educação e interpretação ambiental e que de acordo com Ferreira (2005, p.25) tem por objetivo "[...] a conservação dos recursos naturais, em geral de remanescente de vegetação em área que estão sob pressão dos impactos gerados por diversos fatores decorrentes da urbanização". Também podem ser denominadas florestas urbanas, segundo Paiva e Gonçalves (2002, p.20) são "[...] áreas verdes de preservação e/ou conservação [...] cuja finalidade é a conservação do sitio ou a manutenção da biodiversidade".

Com base nas diretrizes do SNUC as UCs foram pensadas para proteger áreas de relevante interesse ambiental situadas em espaço rural, contando com áreas de amortecimento, para amenizar os conflitos com as áreas de entorno. (BRASIL, 2000).

Fazer com que se alcance os objetivos de preservação das UCs em espaço rural é uma tarefa complexa e difícil que se multiplica quando estas se localizam em espaço urbano. A começar pela dificuldade de execução dos procedimentos relacionados à proteção, fiscalização e interação com as comunidades de entorno.

A literatura acadêmica está repleta de exemplos de estudos das situações conflituosas entre os objetivos propostos para as Unidades de Conservação, localizadas em área rural, e moradores do seu entorno e em muitos casos também presentes em seu interior. Sendo que, por exigência da legislação não é permitido a intervenção humana nos seus ambientes protegidos, como é o caso dos Parques e das Reservas da Biosfera.

Nesse contexto, podem-se citar os estudos de Oliveira (2005) que apresenta importante análise dos conflitos existentes no Parque Estadual da Serra do Tabuleiro, em Santa Catarina. A partir das suas investigações, o pesquisador apresenta mecanismos de gestão para esses conflitos. Também em DelgadoMendez (2008) encontra-se significativa análise investigativa realizada em duas UCs de Proteção Integral - a REBIO do LAGO, no Amapá e o Parque Estadual de Itaúnas (PEI), no Espírito Santo. O autor debate sobre o sucesso da proteção dessas áreas sem, contudo deixar de considerar o desenvolvimento social das comunidades diretamente afetadas quando da instituição de uma 
Unidade de Conservação. Pimentel (2008), dedica-se a outro estudo relevante sobre esse tema, quando discute a questão da inserção social em Parques, para tanto o pesquisador utiliza-se das análises realizadas no Parque Estadual da Serra da Tiririca (PESET), no Estado do Rio de Janeiro.

Entretanto, estudos realizados em UCs localizadas em espaço urbano, na modalidade Parque, também são muitos, porém, limitam-se em analisar as atividades impactantes das atividades urbanas sobre estas áreas protegidas, além de buscar identificar a percepção dos moradores e também dos usuários, entre outras questões correlatas. Assim, percebe-se uma carência de estudos que identifique as reais causas dos conflitos de uso entre moradores e UCs, podendo vir a contribuir com a integração das áreas protegidas e as áreas urbanizadas.

De acordo com Porfírio et al (2006, P. 1034) "[...] as florestas urbanas sofrem grandes impactos devido à pressão antrópica no seu interior e no seu entorno", pois de acordo com os autores "[...] os habitantes de uma cidade não são uma categoria homogênea e, por isso, têm diferentes necessidades e percepções dos espaços verdes urbanos". E, essas diferenças irão influenciar de forma decisiva na interação dos moradores de entorno de uma unidade de conservação.

Para Silva e Egler (2002 p. 8 -9),

\begin{abstract}
As áreas verdes nos espaços urbanos encontram dificuldades, pois os espaços livres enfrentam uma intensa pressão da urbanização acelerada, por exemplo, no caso brasileiro, a população urbana dobrou em 46 anos. E muitas vezes, mesmo com toda a sua importância tornam-se inviáveis frente aos interesses econômicos dos atores que atuam na organização do espaço urbano. À medida que se estrutura o arranjo dos atores no meio urbano, sua alocação de poder e produção dos seus interesses frente a outros acirram-se os conflitos. Espaço de disputas, essa é a percepção moderna de áreas destinadas a parques urbanos, principalmente onde eles ainda não existem, pois se encontram apenas sob forma de lei.
\end{abstract}

Os impactos observados em Unidades de Conservação de proteção integral, situadas em meio urbano se repetem nas diferentes cidades brasileiras. E independem do porte da cidade, dos órgãos que não possuem recursos humanos, técnicos e materiais adequados, do estágio de civilidade da comunidade de entorno, entre outros fatores. Tornam-se alvos de severas 
perturbações, como constantes incêndios, captura de animais silvestre, invasão de espécies de fauna doméstica, furtos, vandalismo com os equipamentos, destruição do bem público, deposição de resíduos, entre outros.

As perturbações acima mencionadas, entendidas aqui como conflitos de uso poderiam ser minimizadas se a participação efetiva da população local tivesse sido garantida, no momento da constituição da unidade, da elaboração do plano de manejo e da sua implementação. A degradação de áreas protegidas, além das causas já citadas, relaciona-se às formas de condução das políticas conservacionistas, onde a relação da comunidade deve se adaptar aos conceitos prontos, identificados por Cattaneo (2004) como os grandes responsáveis pela geração de conflitos entre comunidade e área protegida, mas poderiam ser amenizados caso os conceitos fossem adaptados à realidade do lugar onde se insere uma Unidade de Conservação, no caso a cidade.

Ainda de acordo com Cattaneo (2004, p. 65), o modelo de unidades de conservação que fazemos uso, "[...] tende a dicotomizar homem e natureza, hierarquizando as relações e classificando, de forma estanque, os elementos humanos e naturais".

Entretanto, considera-se que os principais problemas das Unidades de Conservação localizadas em espaço urbano estão na sua finalidade, nos objetivos traçados pela legislação ambiental brasileira que prioriza a preservação dos componentes naturais sem considerar os interesses e as necessidades das populações urbanas, na contra cultura da conservação e do valor patrimonial da área para as populações urbanas.

Assim, consultar a comunidade sobre suas necessidades de espaços públicos para lazer e também avaliar a qualidade da infraestrutura ofertada no entorno de um dos módulos constituintes do Parque Municipal Cinturão Verde - Módulo Mandhuy, além de detectar os conflitos de interesse em relação à área preservada, consiste nos objetivos desse estudo, que foi realizado na cidade de Cianorte - PR, localizada no Noroeste do Estado. 


\section{MATERIAIS E MÉTODOS}

\subsection{Caracterização da área}

Em Cianorte, segundo dados da Secretaria Municipal do Meio Ambiente (2008), o percentual de vegetação atualmente encontrado é de 13,77\% da área do município, o que corresponde a 11.176,20 ha de cobertura vegetal. $O$ espaço territorial de Cianorte equivale a $813,7 \mathrm{Km}^{2}$. O total de área com vegetação original, quando comparado a dados do Estado, é relevante, pois o território do Paraná, de acordo dados da Fundação S.O.S. Mata Atlântica (1998) possui menos de $8 \%$ de cobertura vegetal.

No Município de Cianorte os remanescentes florestais não se distribuem de maneira ideal por sobre o território do município. Concentram-se em pequenas ilhas de matas geralmente já bem exploradas, em fazendas da CMNP (Companhia Melhoramentos Norte do Paraná) e próximas ao perímetro urbano. Entretanto, constata-se que as madeiras de lei já foram retiradas, compondo o que se acostumou a denominar "Cinturão Verde de Cianorte", compreendendo uma área de um pouco mais de 300 hectares $\left(311,99\right.$ ha ou $\left.31.199,35 \mathrm{~m}^{2}\right)$, onde se incluem os 20,97 hectares da área do primeiro módulo criado, o Módulo Manduhy. A vegetação ainda presente no perímetro urbano de Cianorte acompanha linearmente os cursos d'água localizados na malha urbana. (Figuras 1) 


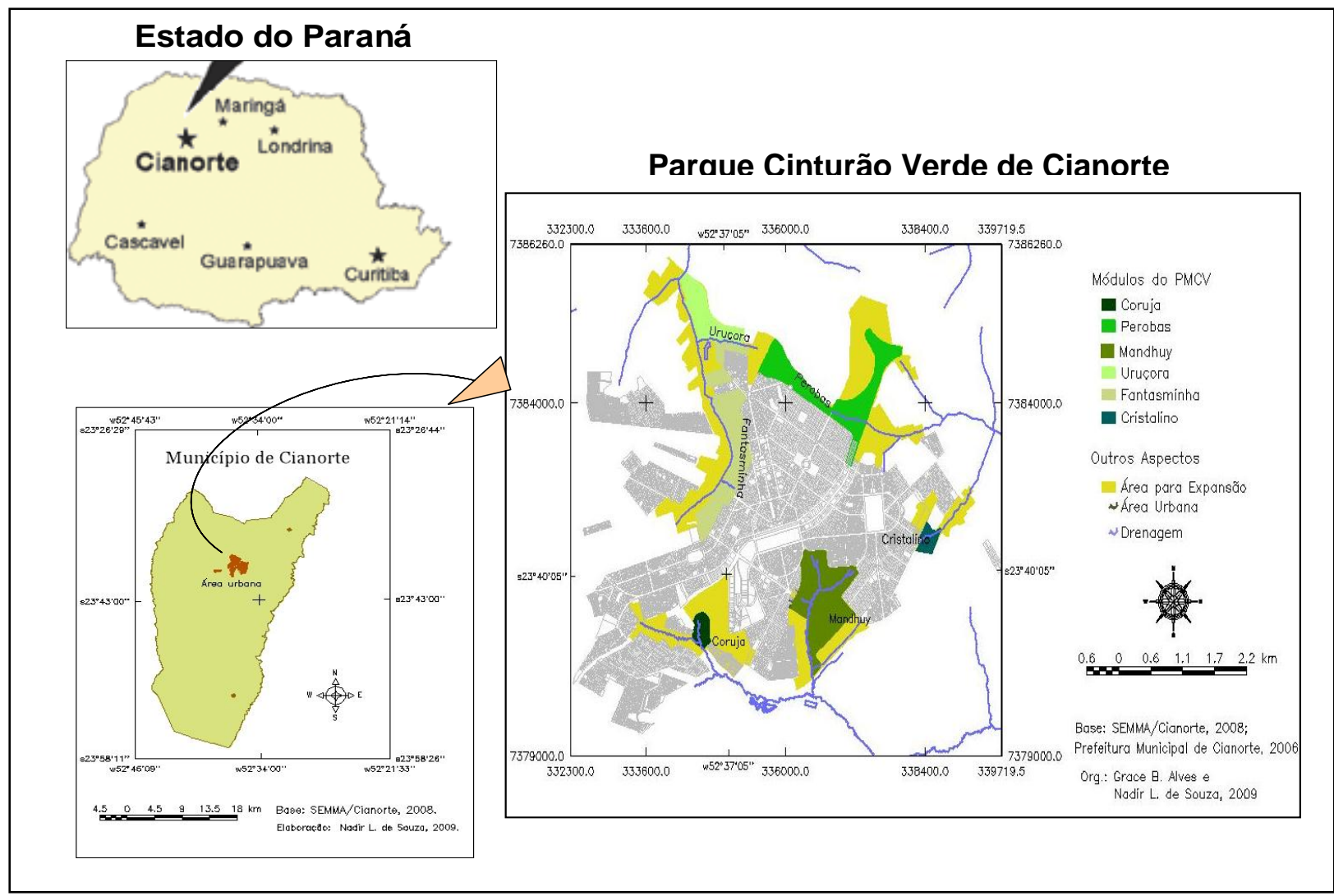

Figura 1 - Localização Município-Estado do Paraná do Parque Cinturão Verde de Cianorte

Em 14 de junho de 1988, a Lei Municipal no 1.098, transformou essa área, em "Sitio Ecológico de Relevância Cultural" a qual passa a ser denominada de "Parque do Cinturão Verde de Cianorte" e, em 7 de dezembro de 1993, através da Lei Municipal 57 n 1.534, cria-se o "Parque Municipal do Cinturão Verde de Cianorte - Módulo Mandhuy", com área total de $209.763,47 \mathrm{~m}^{2}$ objeto do presente estudo

Em 28 de abril de 2000, a CMNP, proprietária de quase todos os fragmentos vegetais, presentes no sitio urbano do Município de Cianorte, doou mais áreas vegetadas para o Município que, através da Lei Municipal nำ2.067, criou o Parque Cinturão Verde de Cianorte com a área atual de 311 hectares, conforme escritura pública lavrada às fls. 140/148, Livro 219-N do $2^{\circ}$ Tabelionato de Notas da 61 Comarca de Cianorte. Nesse momento foram anexados às novas áreas o Módulo Mandhuy composto pela quadra $\mathrm{n}^{\circ}$ 57-A, na Zona 03 (20,9763 hectares) e o Lote de Reserva florestal do Loteamento "Century Park" (8,645808 hectares). (Figura 2) 


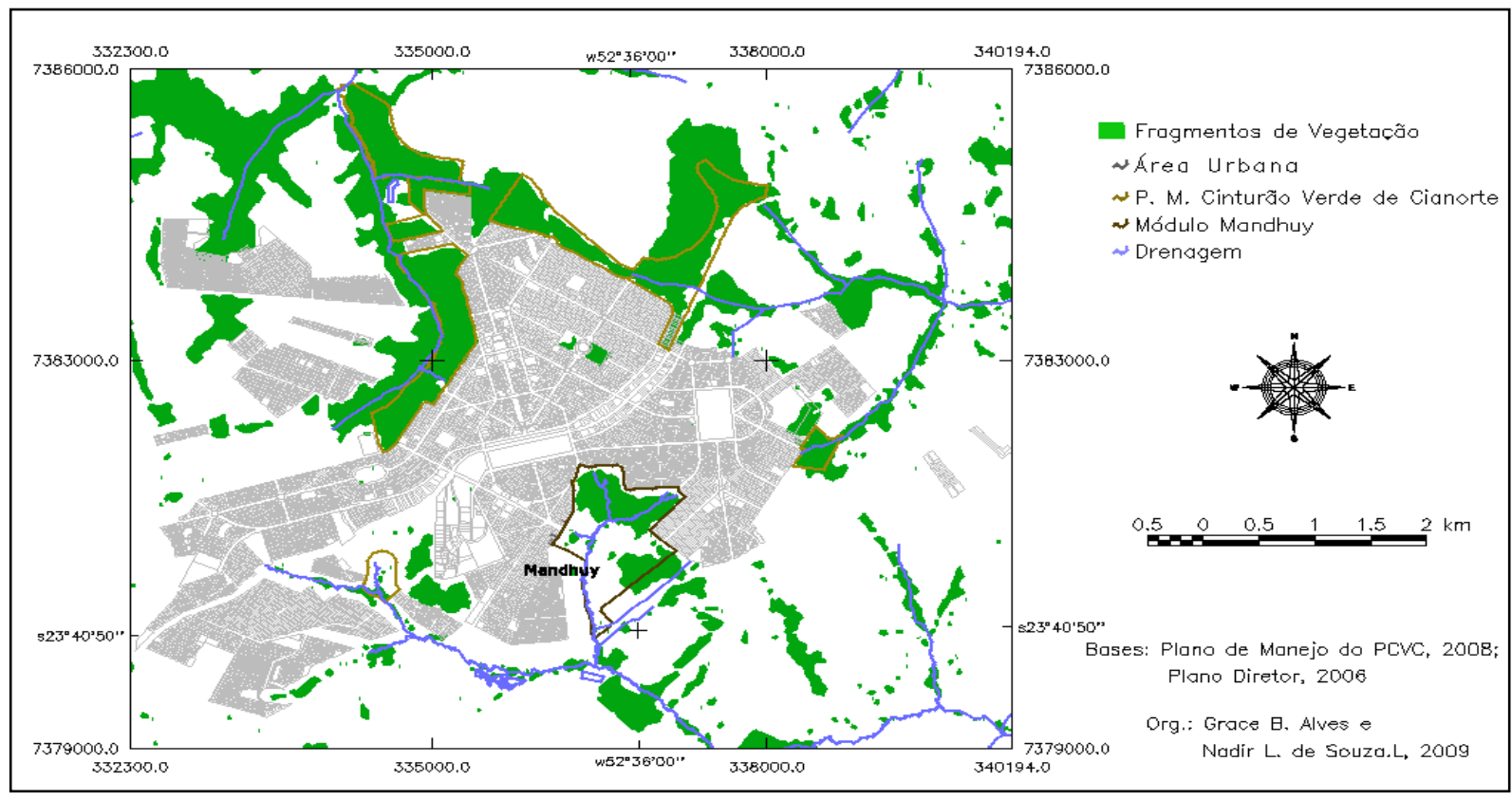

Figura 2 - Fragmentos de vegetação nativa na área urbana de Cianorte

O Parque Cinturão Verde de Cianorte - PCVC - é constituído por vários módulos que representam fragmentos vegetais separados um do outro pela urbanização. Atualmente o Parque é dividido em seis módulos, a saber: Manduhy, Cristalino e Corujinha. Estes se encontram bem distantes uns dos outros, além dos módulos Fantasminha, Uruçora e das Perobas, onde os módulos Fantasminha e Uruçora são conectados e o Módulo das Perobas separa-se dos demais por uma Rodovia, além de ser atravessado por uma estrada vicinal, assim como o Módulo Fantasminha que é cortado por uma estrada de ligação para os novos loteamentos que estão se configurando na sua porção oeste do plano original da cidade.

De acordo com lei que institui o SNUC, o Parque Cinturão Verde de Cianorte constitui uma Unidade de Conservação Integral de uso restrito, com a finalidade de preservação, educação ambiental e realização de pesquisas científicas. 


\subsection{Caracterização física e resultados da avaliação do estado situacional do Módulo Mandhuy}

O Módulo Mandhuy, objeto desse estudo, que desde 1993, data da sua criação, até o ano 2000 representava sozinho o Parque Municipal do Cinturão Verde de Cianorte, localizado na Zona 3, fazendo divisa com a Zona 7 e 0 Conjunto Moradias Marselha, região sul do perímetro urbano do município de Cianorte/Pr, atualmente compreende 88,7619 hectares, dos quais 20,97 correspondem à primeira área que foi regularizada como área de preservação ambiental em 1993. (Figura 3)

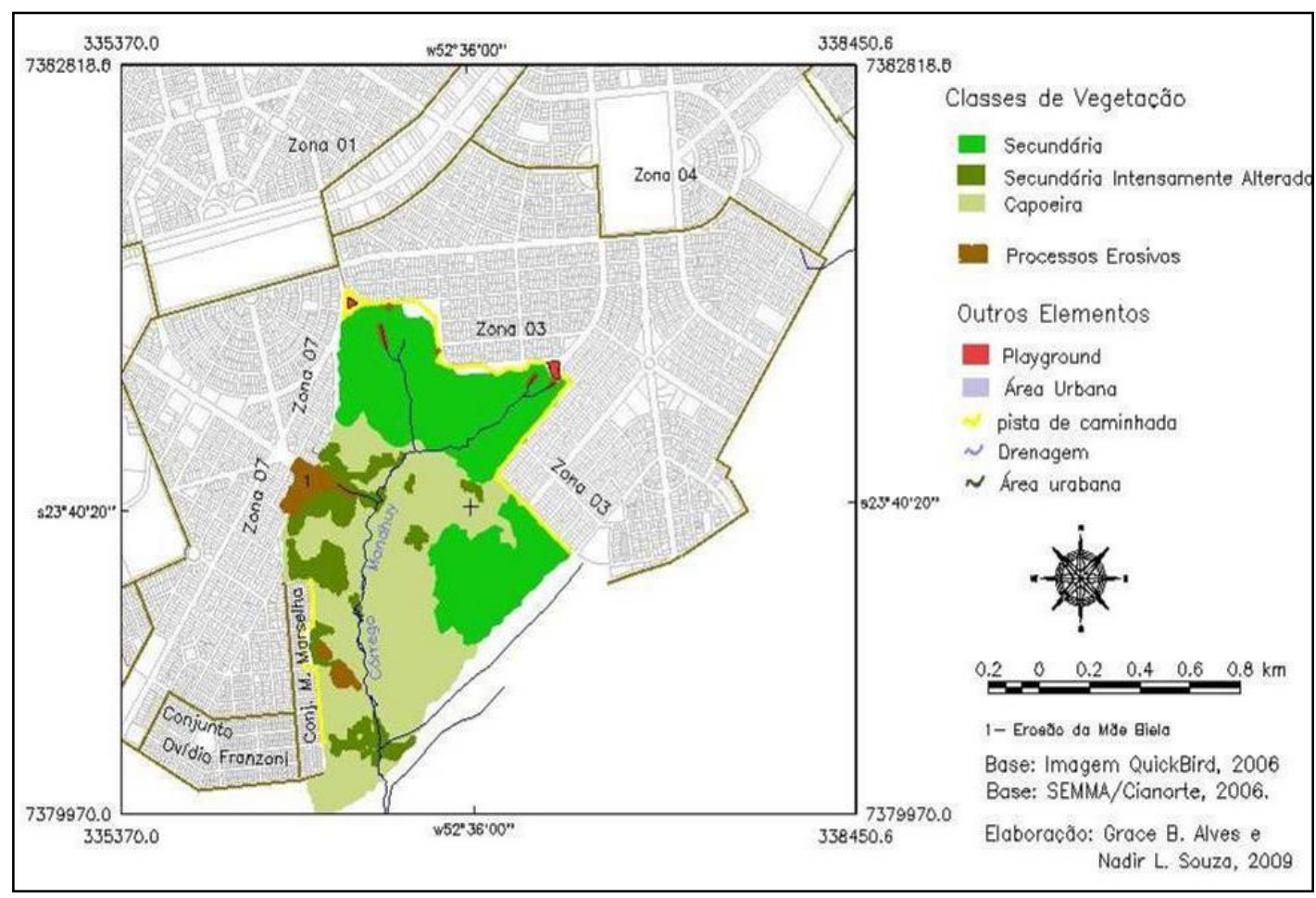

Figura 3: Módulo Mandhuy - Parque Cinturão Verde de Cianorte

A seguir será apresentada a caracterização física do Módulo Mandhuy, abordando seu sistema de drenagem, a tipologia dos solos, os processos erosivos e a cobertura vegetal.

A área do Módulo Mandhuy corresponde a quase total extensão da bacia do córrego de nome homônimo, cujas nascentes se encontram dentro da área do módulo. O córrego Mandhuy é afluente da margem esquerda do córrego 
Curuá, inserido entre os bairros Zona 3, Zona 7 e Conjunto Moradias Marselha no sul, limitado pela Rodovia BR 323.

Dados do Plano de Manejo da UC (2008), o córrego Mandhuy apresentam 4. $068 \mathrm{~m}$ de comprimento, na área do módulo. O referido córrego possui diversos canais, até de $3^{\underline{a}}$ ordem, formando o maior conjunto em relação aos cursos d'água dos demais módulos do PCVC.

O corpo d' água presente na área de estudo não é um escoadouro direto de esgoto da região onde se encontra o Módulo da referida UC, tendo em vista a existência de rede de esgoto nos bairros que circundam em parte o perímetro do parque. Porém, observou-se uma coloração escura da água, mas sem, no entanto, apresentar qualquer odor em nenhum ponto ao longo do curso de água.

Em análises laboratoriais das águas do Córrego Mandhuy, realizadas durante a elaboração do Plano de Manejo em 2008 constatou-se que suas águas apresentam elevados índices de coliformes fecais, indicando possível contaminação por esgoto clandestino. A suspeita da presença de efluentes domésticos no curso d'água também se fundamenta pelo grande contato com as águas pluviais, transportadas por tubulações de concreto que alcançam os veios d'água. A probabilidade de existirem ligações clandestinas de esgoto nas galerias de águas pluviais é grande, tendo em vista que, durante as observações de campo, num dia sem chuva, percebeu-se constante fluxo de água nas galerias internas do Módulo, com espuma, denunciando a presença de sabões e detergentes utilizados em ambiente domésticos ou mesmo em estabelecimentos comerciais da área de entorno do Mandhuy, confirmando a suspeita acima.

Contribuem para o problema o fato das galerias pluviais dos bairros de entorno do Parque terem sido direcionadas para o interior da bacia do Mandhuy e, em dias chuvosos, conduzem todo tipo de material que pode adentrar pelas bocas de lobo.

$\mathrm{Na}$ área do Módulo Mandhuy, os solos inventariados foram os Latossolos Vermelhos típicos textura média que ocupam a maior parte do território do referido módulo. Esse solo apresenta alta concentração de alumínio e intensa 
fragilidade, com baixa capacidade de revegetação. Atividades antrópicas em sua área de ocorrência podem desencadear processos erosivos intensos, causando prejuízos irreparáveis.

Outro solo encontrado na área do Módulo Mandhuy refere-se ao Argissolos Vermelhos Alumínicos textura média que, de acordo com a classificação brasileira de solos, são constituídos por argilas de atividade baixa e horizonte $\mathrm{B}$ textural, com profundidades variáveis, desde forte a imperfeitamente drenados, de cores avermelhadas ou amareladas, brumadas ou acinzentadas. "A textura varia de média muito argilosa no horizonte $\mathrm{BT}$, sempre havendo aumento de argila daquela para este" (Secretaria Municipal do Meio de Cianorte, 2008, p. 41). Esse solo é encontrado no setor Sul do Módulo Manduhy e também acompanhando parte dos canais de drenagem.

Os Neossolos Quartzênicos Órticos típicos foram encontrados em um pequeno trecho no setor Leste do Módulo em tela, acompanhando um dos canais de drenagem que se junta ao córrego Mandhuy. Como característica, apresenta "[...] horizonte A arenoso de coloração mais escura, com pouca aderência a tradagem e horizonte $B$ com textura arenosa de coloração mais clara". (Secretaria do Meio Ambiente de Cianorte, 2008, p. 43). Estes solos são extremamente frágeis com elevados teores de areia e quantidades irrisórias de argila em superfície. Quando ocorre o desflorestamento em áreas com esse tipo de solo, os processos erosivos são imediatos.

Devido às características físicas do solo e a forma de ocupação na área do Módulo Mandhuy, desencadeou-se significativo processo erosivo, sendo que uma das voçorocas tornou-se conhecida como o "Buracão da Mãe Biela", situada no setor oeste do Modulo Mandhuy, na periferia da Zona 7. O nome Mãe Biela deve-se ao fato de uma senhora residente no bairro, chamar-se "Mãe Biela", que perdeu sua casa para a erosão.

As cicatrizes deixadas na área, em função da grande perda de solo, foram aos poucos incorporadas pela população para acondicionar todo tipo de material descartável, lixo. As voçorocas foram, em alguns pontos, e ainda são, destinadas à deposição de resíduos domésticos, resíduos do mobiliário, pneus 
e entulhos da construção civil. Mais tarde, essa prática foi acolhida e incentivada pelo poder público do município.

A vegetação primitiva dessa área e de todo o município de Cianorte é representada pela Floresta Estacional Semidecidual, e que foi, ao longo da evolução histórica do Município, modificada.

A cobertura vegetal presente no Módulo Mandhuy se encontra em diferentes estágios, desde áreas completamente descaracterizadas no seu aspecto fitofisionômico até áreas em avançado estado de regeneração natural. As áreas onde a vegetação se encontra em estágio avançado de regeneração são os setores leste-nordeste, que correspondem ao bosque proposto no Plano Urbanístico (área com 20,97 hectares) e uma faixa na porção sudeste.

A modificação da paisagem vegetal dessa área deve-se ao corte indiscriminado das espécies mais valiosas e aos incêndios constantes, o que resultou numa condição de extrema degradação, onde cerca de 64 ha encontram-se recobertos por capoeira, constituída basicamente por Panicum maximum Jacq. (Capim-colonião), samambaias, e Ricinus communi L. (mamona). Outra espécie agressiva encontrada nas bordaduras da área do Mandhuy é a Leucaeana leucocephala (leucenas), além da Melia azedarach L. (Santa bárbara ou cinamomo). No Plano de Manejo, elaborado em 2008, foi recomendada a retirada imediata dessas espécies.

O revestimento florístico dessa área, mesmo em elevado estado de degradação, desempenha papel de suma importância no equilíbrio hidrológico, atuando nos processos de evapotranspiração, infiltração, impacto da gota no solo e acumulação no lençol freático. A manutenção da vegetação, além de assegurar hábitat e proteção para fauna, é um elemento importante no equilíbrio dos ecossistemas naturais e modificados pela ação humana.

Mesmo com uma paisagem vegetal muito alterada, na área do Mandhuy, é possível encontrar alguns mamíferos e aves. Quando do levantamento realizado para elaboração do Plano de Manejo em 1994, foi encontrada no módulo, a espécie Cebus apella (macaco-prego), porém não tem sido mais vista na área. Essa espécie atualmente é encontrada nos módulos Fantasminha, Uruçora e Perobas. Além das espécies listadas acima, 
encontram-se diversas espécies de morcegos, cobras e tatus (Secretaria do Meio Ambiente de Cianorte, 1994)

Curiosamente a avifauna é muito rica e diversificada. Basta circular ao redor do Mandhuy, em qualquer horário do dia, para avistar dezenas de pássaros, de vários tamanhos, cores e cantos diferenciados. Fato também curioso é que os moradores do entorno e áreas mais distantes não caçam mais esses animais. Segundo alguns moradores, caso seja visto alguém capturando alguma ave, imediatamente avisam a polícia.

Convivendo com a fauna do Mandhuy, estão os animais domésticos que são, por lei, proibidos dentro de UC's, dada a possibilidade de contaminação da flora - por meio de suas fezes (eqüinos e muares) e da fauna por intermédio de doenças e caça.

É muito comum encontrar gatos e cães abandonados. que transformaram o Mandhuy em seu lar, aproximando-se das residências para buscarem alimentos. No entanto, esses animais domésticos constituem em clara ameaça à fauna do Parque. Mas, por outro lado, são animais próprios da fauna urbana, como os ratos, as baratas, as pombas e os pardais, produtos da cultura das sociedades que há milhares de anos foram domesticados e aprenderam a conviver com os humanos. Logo, podemos inquirir, se essas duas faunas, a do Mandhuy e a doméstica, não podem conviver no mesmo espaço, qual delas está em local equivocado?

\subsection{Infraestrutura do Módulo Mandhuy}

A infraestrutura presente no Módulo Mandhuy ainda é muito incipiente apesar de ser a área mais antiga formadora do Parque Municipal Cinturão Verde de Cianorte. Ao longo de parte do entorno da Zona 3 estão dispostos os equipamentos desse módulo, como lixeiras, bancos, placas, dois parques infantis, dois mini campos de futebol, a pista de caminhada e um vasto gramado que emoldura parte da área.

A pista de caminhada apresenta cerca de $2.400 \mathrm{~m}$ de extensão, contornando o setor da Zona 3. Além desta, há outra construída recentemente defronte ao Conjunto Residencial Moradias Marselha, no Setor Oeste do Módulo Mandhuy, 
com aproximadamente $700 \mathrm{~m}$ de extensão. $\mathrm{O}$ trecho da pista entre a Avenida Maranhão e o início da Rua Juruá é muito utilizado por ciclistas, como via de ligação entre os dois bairros, a Zona 3 e a Zona 7, sob a alegação de que as ruas, nesse trecho, são muito perigosas em função do intenso tráfego de veículos.

As lixeiras, em número de dez, foram confeccionadas em ferro e presas a suportes também desse material fixado no solo com concreto. Algumas foram alvos de vandalismo e se encontram amassadas, retorcidas ou simplesmente foram arrancadas e desapareceram. Uma dessas lixeiras é bem maior que as demais e se encontra instalada em frente à sede da Secretaria de Meio Ambiente de Cianorte (SEMMA), para incentivar os moradores daquele trecho a depositar resíduos recicláveis e não dispô-los no interior do Módulo.

Os bancos de descanso encontram-se dispostos ao longo da pista de caminhada, e nas áreas dos parques infantis, num total de dezoito bancos. Desses, dez foram confeccionados em madeira (encosto e assento) e suporte de cimento, fixados no solo. No parque infantil do extremo norte da pista, divisa com a Avenida Maranhão, há seis bancos, e dois no parque infantil do setor extremo leste, próximo à Avenida Piauí, esquina com Rua Piquiri. Esses bancos foram os primeiros a serem instalados na área e fabricados inteiramente em madeira tratada.

As placas informativas são de diversos tamanhos e estão dispostas ao longo do entorno da Zona 3. Essas placas encontram-se em estado crítico de conservação. Das vinte e seis placas presentes nessa área, dez estão em boas condições; seis placas foram arrancadas e desapareceram, restando apenas as duas madeiras do suporte. Dez placas encontram-se muito danificadas, devido aos chutes e pontapés de vândalos, além das pixações a que foram submetidas, inutilizando-as.

Nesse Módulo há duas áreas de recreação infantil, e em uma delas localizam-se os poucos equipamentos de ginástica existentes neste módulo. Os equipamentos das áreas de recreação para crianças não passam por processos de manutenção, sendo que alguns estão danificados e já não cumprem mais sua função. Parte dos danos causados nesses equipamentos é 
resultado da sua utilização por adultos, com peso e altura muito superiores aos das crianças para as quais os equipamentos foram instalados.

Os equipamentos dos brinquedos dos parques infantis foram confeccionados em toras de eucalipto tratado, combinando harmoniosamente com a paisagem natural da área, conferindo-lhe certa rusticidade.

Estão presentes nessa área: um escorregadouro de metal inadequado à recreação, pois, em horários de maior temperatura do dia, não é possível utilizá-lo sob o risco de ocorrer queimaduras; uma gangorra; balanço e uma travessia alta.

Outra questão que traz preocupações às mães é a falta de cerca para isolar o parque infantil das vias de trânsito. Segundo as mães, essa área, da forma em que se encontra atualmente, é muito perigosa, pois as crianças correm em direção às ruas de entorno, local de intenso tráfego nos períodos da manhã e tarde, horário em que as mães costumam levar os filhos ao parque.

A iluminação da área é a mesma da rua. Em alguns pontos da pista, quando esta se afasta da rua, a mesma fica muito escura. Nos dois parques infantis há superpostes, tipo trevo. Há ainda mais outros quatro superpostes dispersos pelo gramado do lado leste/nordeste da área.

Os mini campos de futebol, instalados nessa área, são pouco utilizados. Aquele que se localiza na área de recreação está com sua área ameaçada pelo processo erosivo, que se instalou em uma das suas laterais (cerca). Essa área já foi palco de intensa atividade erosiva e encontrava-se já há algum tempo estabilizada. A área foi recuperada e aproveitada para a instalação de espaço recreativo.

\subsection{Procedimentos Metodológicos}

Os procedimentos metodológicos adotados para este estudo consistiram no desenvolvimento de uma série de atividades que atendessem aos objetivos propostos. Assim sendo, fez-se levantamento bibliográfico e documental relacionados à legislação e conceituação das Unidades de Conservação, além de materiais específicos que tratam do processo de constituição do Parque Municipal Cinturão Verde de Cianorte - Módulo Mandhuy. Outros dados que 
foram relevantes para a composição desse estudo referem-se à importância das áreas verdes urbanas e também dos parques urbanos, elementos vitais no espaço citadino. Para tanto, foram consultados periódicos, fotos, imagens de satélites, mapas e artigos de jornais.

Para conhecer a opinião dos usuários do parque foram realizadas entrevistas realizadas pela autora, que contou com a colaboração de dois estagiários previamente treinados, alunos do Ensino Médio do Colégio Estadual D Bosco, ao longo dos meses de novembro e dezembro de 2008 e janeiro e fevereiro de 2009. A aplicação do questionário deu-se em todos os dias da semana (segunda feira a domingo) e dois períodos (manhã e tarde). As perguntas contidas nos questionários buscaram, primeiramente, traçar 0 perfil do usuário (idade, sexo, renda familiar) bem como identificar as reais necessidades em termos de infraestruturas para a prática de atividades de lazer gratuito e aspectos gerais de qualificação da relação dos usuários com o referido espaço.

O critério para a escolha dos entrevistados foi o de abordar pessoas com mais de 15 anos, sem limite superior de idade, desde que aptos a responder a todas as questões do questionário, procurando-se manter o princípio da aleatoriedade em relação a gênero e idade. A abordagem ocorreu quando essas faziam uso da pista de caminhada, dos parques infantis, dos minicampos de futebol ou encontravam-se sentados nos bancos. A partir do pressuposto descrito efetuou-se um total de 100 (cem) entrevistas com usuários do Módulo Mandhuy.

A amostra empregada neste estudo foi a não probabilística por julgamento que se define como sendo aquela na qual o pesquisador seleciona o que acredita ser a melhor amostra diante do seu problema de pesquisa (ROCHA, 2006; OLIVEIRA, 2001). A investigação com os usuários do Módulo Mandhuy teve como base experiências de estudos anteriores realizados em outros parques do Brasil, sendo relevantes as pesquisas de Ferreira (2005), Ballarotti (2005), Biondi e Mórmul (2004). 


\section{RESULTADOS E DISCUSSÃO}

\subsection{Análise do perfil socioeconômico dos usuários entrevistados}

Para se compor o perfil dos usuários, agruparam-se os dados a respeito de gênero, escolaridade, faixa etária, renda familiar, ocupação, horas diárias de trabalho e o bairro de procedência, além da distância percorrida para acessar o parque. Os dados da entrevista estão dispostos no Quadro 1.

a) - Gênero - Verificou-se que a maioria dos frequentadores do Módulo Mandhuy é composta por mulheres, representando 54\% dos entrevistados. Entretanto, a diferença, não é significativa, sem contar que a maioria das mulheres realiza atividades físicas em grupos de duas ou mais, sob alegação de que o fazem dessa forma, por se sentirem mais seguras e também aproveitam o momento para "colocar a conversa em dia", como informou uma entrevistada que alegou "ser este momento de terapia".

b) - Faixa etária - A idade dos entrevistados apresentou-se bem distribuída entre as classes representadas em que se verifica que grande parte dos frequentadores do Mandhuy é composta por adultos, cerca de 57\%, com idade entre 21 e 50 anos. O grupo mais expressivo das mulheres encontra-se na faixa entre 41 a 50 anos, enquanto que os homens são maioria na faixa entre 15 a 20 anos.

c) - Escolaridade - A maioria dos frequentadores do Mandhuy (82\%) possui apenas a escola básica - Ensino Fundamental e Médio.Muitos jovens das classes operárias abandonam a escola diante da necessidade de ajudar economicamente a família, o que mais tarde vai reforçar o número de adultos com pouca ou quase nenhuma escolaridade. Constatou-se nesse estudo que $5 \%$ dos entrevistados, nesse estudo, não são alfabetizados.

d) - A renda familiar que é composta pelos ganhos com o trabalho remunerado de todos os membros da família, incluindo as aposentadorias, pensões e outros benefícios, apresentou maior frequência nas classes entre um a cinco salários mínimos (R\$415,00). 
e) - Ocupação - Pelas análises dos dados, notou-se que praticamente metade dos entrevistados (48\%) encontra-se empregado, sendo que os índices entre os gêneros são bem semelhantes.

É também importante o número de mulheres que se identificaram como do lar, mas fizeram questão de informar que realizam atividades para complementar a renda da família, como bordados, confecção de alimentos (salgados) e cuidados com crianças, entre outros.

O bairro de procedência da maioria dos usuários do Mandhuy é o Zona 3 (78\%), e isso é facilmente explicável, pois a pista de caminhada, os parques infantis, os míni-campos de futebol, os aparelhos de ginásticas, os espaços com grama, enfim tudo o que se refere a infraestrutura está disposta no entorno desse bairro. O segundo grupo (13\%) dos usuários procedem da Zona 7, setor do Mandhuy, sem nenhuma infraestrutura.

Não foi identificado nenhum usuário residente no Conjunto Moradia Marselha. A explicação para essa ausência está no fato de que o referido conjunto habitacional encontra-se espacialmente muito distante da área do entorno do Mandhuy que oferece certa infraestrutura. A partir do mês de fevereiro de 2009, a Prefeitura Municipal de Cianorte iniciou a construção de uma pista de caminhada com aproximadamente $700 \mathrm{~m}$ de extensão, passando a atender, em parte, às necessidades, pelo menos de caminhadas e corridas, dos moradores do Conjunto Moradias Marselha e arredores.

Estão identificados na Figura 1 os bairros de onde procede a maior parte dos usuários entrevistados, bem como a infraestrutura disponível na parte externa do Módulo Mandhuy, utilizada por estes.

Pouquíssimos usuários vêm de outros bairros, como da zona 1 (Centro), Zona 4, conjuntos Habitacionais: São Francisco e Ovídio Franzoni, estes são vizinhos do Conjunto Moradias Marselha. Os moradores dos bairros zona $1 \mathrm{e}$ zona 4 residem mais próximos dos outros módulos formadores do PCVC, enquanto que os moradores do Conjunto Residencial São Francisco e Ovídio Franzoni, provavelmente utilizarão a infraestrutura que esta sendo construída defronte ao Conjunto Residencial Moradias Marselha, como já expusemos. 
A questão 7, que investiga a distância, em quadras, para se chegar ao Parque, confirma a acessibilidade dos moradores da Zona 3, pois a maioria destes residem mais próximo da área equipada do entorno do Mandhuy, logo podem utilizá-la com mais frequência que os moradores dos demais bairros.

Quadro 1 - Resumo do perfil dos usuários do Módulo Mandhuy

\begin{tabular}{|c|c|c|c|c|c|c|c|c|c|c|c|c|}
\hline $\begin{array}{l}\text { Elementos } \\
\text { de Análise }\end{array}$ & \multicolumn{12}{|c|}{ Categorias } \\
\hline \multirow{2}{*}{ Gênero } & \multicolumn{2}{|c|}{ Masculino } & \multicolumn{2}{|c|}{ Feminino } & & & & & & & & \\
\hline & \multicolumn{2}{|c|}{$46 \%$} & \multicolumn{2}{|c|}{$54 \%$} & & & & & & & & \\
\hline \multirow{3}{*}{$\begin{array}{l}\text { Faixa etária } \\
\text { (anos) \% }\end{array}$} & \multicolumn{2}{|c|}{15 a 21} & \multicolumn{2}{|c|}{21 a 30} & \multicolumn{2}{|c|}{31 a 40} & \multicolumn{2}{|c|}{41 a 50} & \multicolumn{2}{|c|}{51 a 60} & \multicolumn{2}{|c|}{ Maior de 60} \\
\hline & M & $F$ & M & $F$ & M & $\mathrm{F}$ & M & $F$ & M & $\mathrm{F}$ & & $\mathrm{F}$ \\
\hline & 11 & 3 & 9 & 6 & 3 & 12 & 10 & 17 & 2 & 5 & & 11 \\
\hline \multirow[t]{2}{*}{ Escolaridade } & \multicolumn{2}{|c|}{$\begin{array}{c}\text { Ensino } \\
\text { Fundamental }\end{array}$} & \multicolumn{2}{|c|}{ Ensino Médio } & \multicolumn{2}{|c|}{$\begin{array}{c}\text { Pós- } \\
\text { Graduação }\end{array}$} & \multicolumn{2}{|c|}{$\begin{array}{l}\text { Nível } \\
\text { Superior }\end{array}$} & \multicolumn{3}{|c|}{$\begin{array}{c}\text { Sem } \\
\text { Escolaridade }\end{array}$} & $\begin{array}{c}\text { Não } \\
\text { informou }\end{array}$ \\
\hline & \multicolumn{2}{|c|}{$51 \%$} & \multicolumn{2}{|c|}{$31 \%$} & \multicolumn{2}{|c|}{$8 \%$} & \multicolumn{2}{|c|}{$3 \%$} & \multicolumn{3}{|c|}{$5 \%$} & $2 \%$ \\
\hline \multirow[t]{2}{*}{ Renda } & \multicolumn{2}{|c|}{ Até 1 Salário } & \multicolumn{2}{|c|}{$\begin{array}{l}\text { De } 1 \text { a } 2 \\
\text { Salários }\end{array}$} & \multicolumn{2}{|c|}{$\begin{array}{l}\text { De } 2 \text { a } 5 \\
\text { Salários }\end{array}$} & \multicolumn{2}{|c|}{$\begin{array}{l}\text { De } 5 \text { a } 6 \\
\text { Salários }\end{array}$} & \multicolumn{3}{|c|}{$\begin{array}{l}\text { Maior que } 8 \\
\text { Salários }\end{array}$} & $\begin{array}{c}\text { Não } \\
\text { informou }\end{array}$ \\
\hline & \multicolumn{2}{|c|}{$12 \%$} & \multicolumn{2}{|c|}{$35 \%$} & \multicolumn{2}{|c|}{$38 \%$} & \multicolumn{2}{|c|}{$5 \%$} & \multicolumn{3}{|c|}{$5 \%$} & $5 \%$ \\
\hline Ocupação & Emp & ado & $\begin{array}{r}\text { Do } \\
\text { Estc }\end{array}$ & & Autê & omo & $\begin{array}{r}\text { Apos } \\
d c\end{array}$ & nta & Des & mpre & & $\begin{array}{c}\text { Não } \\
\text { Informou }\end{array}$ \\
\hline & & & & & & & 10 & & & $9 \%$ & & $1 \%$ \\
\hline $\begin{array}{l}\text { Procedência } \\
\text { do Usuário }\end{array}$ & Zona & & Zona 0 & & ona 0 & & Zona 0 & & $\begin{array}{l}\text { Co } \\
\text { São F } \\
\text { Ovídi }\end{array}$ & $\begin{array}{l}\text { Je Re } \\
\text { ancis } \\
\text { Fran }\end{array}$ & & $\begin{array}{l}\text { Outras } \\
\text { cidades }\end{array}$ \\
\hline Balrro & $1^{\circ}$ & & $78 \%$ & & $1 \%$ & & $13 \%$ & & & $6 \%$ & & $1 \%$ \\
\hline $\begin{array}{l}\text { Distância do } \\
\text { deslocamento } \\
\text { (em quadras) }\end{array}$ & $1 \mathrm{Q}$ & & 2 Q & & $\begin{array}{l}\text { Mais } \\
\text { Qu }\end{array}$ & $\begin{array}{l}\text { ue } 3 \\
\text { ras }\end{array}$ & & & & & & \\
\hline & & & & & & & & & & & & \\
\hline
\end{tabular}




\subsection{Análise da utilização e da relação do dos usuários do Módulo Mandhuy}

Avaliação dos usos do Mandhuy foi feita analisando a frequência dos usuários, quais os elementos mais atrativos no Módulo, o horário que costumam frequentar, quantas vezes por dia ou durante a semana vêm ao parque, as críticas mais comuns atribuídas ao Mandhuy, os benefícios proporcionados por ele e também às condições de segurança. (Tabela 1).

A escolha do final da tarde para estar no Parque deve-se ao fato de grande parte dos entrevistados (76\%) ser formada por trabalhadores, com empregos formais, também autônomos e donas de casa, que encontram tempo livre somente após suas atividades ocupacionais.

O período da manhã é o mais utilizado pelos idosos, geralmente casais, que preferem esse horário por considerá-lo mais seguro, momento em que a pista de caminhada é bem menos utilizada, tanto por ciclistas como por outros que praticam algum tipo de atividade física. A presença de cães no espaço do Mandhuy amedronta esse grupo de usuários que teme ser atacado, argumentando: "que somos muito velhos para correr".

O número de indivíduos que frequenta diariamente o Mandhuy é praticamente idêntico aos que frequentam entre duas a três vezes por semana, e o fazem ao final da tarde.

Os finais de semana (sábados e domingos) são os dias de menor frequência dos usuários no Mandhuy. De acordo com informações dos mesmos, os afazeres domésticos (lavagem de roupa, mercado, feira, entre outros) são realizados nesses dias. Além de que esses usuários procuram nos finais de semana outros tipos de atividades para a prática de lazer, diferente das opções que a pequena infraestrutura do Mandhuy oferece. 


\section{Tabela 1 - Avaliação do uso do Módulo Mandhuy pelos usuários entrevistados}

\begin{tabular}{|c|c|c|c|c|}
\hline $\begin{array}{l}\text { Frequência de } \\
\text { acordo com } \\
\text { horário }\end{array}$ & $\begin{array}{c}\text { Manhã } \\
32 \% \\
\end{array}$ & $\begin{array}{c}\text { Final da tarde } \\
64 \% \\
\end{array}$ & $\begin{array}{c}\text { Outros horários } \\
4 \% \\
\end{array}$ & \\
\hline Frequência & $\begin{array}{c}\text { Todos os dias } \\
36 \%\end{array}$ & $\begin{array}{c}\text { Segunda a sexta } \\
16 \%\end{array}$ & $\begin{array}{c}\text { De } 2 \text { a } 3 \text { vezes } \\
\text { por semana } \\
38 \%\end{array}$ & $\begin{array}{c}1 \text { vez por semana } \\
1 \%\end{array}$ \\
\hline $\begin{array}{l}\text { Tempo de } \\
\text { Permanência }\end{array}$ & $\begin{array}{c}\text { Até } 1 \text { hora } \\
78 \%\end{array}$ & $\begin{array}{c}\text { De } 1 \text { a } 3 \text { horas } \\
14 \%\end{array}$ & $\begin{array}{c}\text { Mais de } 5 \text { horas } \\
1 \%\end{array}$ & $\begin{array}{c}\text { Não informou } \\
7 \%\end{array}$ \\
\hline $\begin{array}{l}\text { Atividade } \\
\text { realizada }\end{array}$ & $\begin{array}{c}\text { Caminhar } \\
72 \%\end{array}$ & $\begin{array}{c}\text { Esportes } \\
10 \% \\
\end{array}$ & $\begin{array}{c}\text { Descançar } \\
8 \% \\
\end{array}$ & $\begin{array}{c}\text { Caminho / outro } \\
\text { bairro } \\
5 \% \\
\end{array}$ \\
\hline Atração & $\begin{array}{c}\text { O verde } \\
76 \%\end{array}$ & $\underset{10 \%}{O \text { gramado }}$ & $\begin{array}{c}\text { Pássaros } \\
6 \%\end{array}$ & $\begin{array}{c}\text { Campos } \\
4 \%\end{array}$ \\
\hline $\begin{array}{l}\text { Uso de outros } \\
\text { Módulos PCVC }\end{array}$ & $\begin{array}{l}\text { Sim } \\
76 \%\end{array}$ & $\begin{array}{l}\text { Não } \\
13 \%\end{array}$ & $\begin{array}{l}\text { Não Informou } \\
11 \%\end{array}$ & \\
\hline Segurança & $\begin{array}{l}\text { Ótima } \\
1 \%\end{array}$ & $\begin{array}{l}\text { Boa } \\
18 \%\end{array}$ & $\begin{array}{l}\text { Regular } \\
17 \%\end{array}$ & $\begin{array}{l}\text { Péssima } \\
46 \%\end{array}$ \\
\hline
\end{tabular}

Fonte: Pesquisa realizada pela autora no Módulo Mandhuy, Cianorte 2010.

A maioria dos usuários $(78 \%)$ permanece aproximadamente uma hora no Mandhuy, tempo suficiente para completar uma volta na pista de caminhada que possui aproximadamente $2.400 \mathrm{~m}$. Os que informaram permanecer por mais de uma hora são aqueles que realizam outras atividades, e não a caminhada, como: jogar bola, utilizar os parques infantis, soltar pipa, sentar-se nos bancos para "bater papo" ou acompanhar os filhos em suas atividades recreativas.

Quanto à finalidade de uso do Mandhuy (Questão 2), observou-se que $72 \%$ dos entrevistados utilizam-no para a prática de caminhadas e corridas atividades físicas que tem como objetivo primeiro o bem estar físico, assim como a estética corporal, muito na moda atualmente, que imprime a necessidade do corpo 'sarado'.

A prática de esportes no Módulo Mandhuy ainda é muito esporádica, em função da incipiente infraestrutura disponível, e é realizada principalmente nos finais de semana.

Quanto aos atrativos, a maioria dos entrevistados (76\%) considera o verde da mata, ou seja, o elemento natural, o principal atrativo do Mandhuy. Entre as respostas dadas a esse questionamento, o canto dos pássaros foi lembrado principalmente pelos usuários que utilizam o parque no período da manhã, indicando a importância do contato com a natureza, enquanto que os 
equipamentos de infraestrutura presentes no entorno do Mandhuy não foram muito lembrados.

O benefício que o Mandhuy possibilita aos usuários (Tabela 2) é a prática do lazer passivo, expresso na contemplação do espaço, manifestada através do contato deste com a natureza, o que para $63 \%$ dos entrevistados resulta em saúde física e mental.

Quando analisamos a Questão 10 onde os entrevistados indicaram se frequentam ou não outros Módulos do Parque Cinturão Verde, $76 \%$ das respostas foram negativas, indicando que os moradores do entorno do Mandhuy são de fato os seus usuários. Aqueles que disseram ser frequentadores também de outros módulos do Parque Cinturão Verde de Cianorte (13\%) alegaram a organização e os cuidados que os Módulos Fantasminha e Perobas recebem, tornando-os, dessa forma, mais atrativos.

Tabela 2 - Benefícios do Módulo Mandhuy à população

\begin{tabular}{lc}
\hline \hline Benefícios & № absoluto \\
\hline Lazer passivo (contemplação) & 68 \\
Saúde física e mental & 63 \\
Conforto & 13 \\
Outros & 2 \\
\hline \hline
\end{tabular}

Nota: A somatória ultrapassa o no de usuários (100), devido à possibilidade do entrevistado poder escolher várias opções de resposta.

Fonte: Pesquisa realizada pela autora no Módulo Mandhuy, Cianorte 2010.

A distância entre os bairros de entorno do Mandhuy e os outros módulos equipados com pista de caminhada e aparelhos de ginástica, representa um dos fatores que contribuem para a menor frequência desses usuários nos outros módulos do Parque Cinturão Verde, muito embora esta não seja significativa, mas, a proximidade da área com suas residências é decisivo.

A questão 11 - Como você avalia a segurança na área do Parque Mandhuy? - buscou avaliar a segurança oferecida no Mandhuy para os seus usuários. As respostas dadas a esta questão, mesmo acompanhadas de depoimentos, foram agrupadas em algumas categorias em que é possível perceber que a maior parte dos entrevistados apontou a segurança como o item mais preocupante no Mandhuy. 
A área do Mandhuy com 88 hectares de vegetação bem diversificada (mata densa, capoeira, vegetação rasteira) ou inexistente, constitui-se num espaço muito atrativo para a marginalidade transformá-lo em esconderijo para produtos de roubos. Quando os funcionários da Secretaria do Meio Ambiente realizam a limpeza (capina) no interior do Parque, retiram muitas "carcaças" de eletroeletrônicos, como televisores e rádios, e também partes de bicicletas, motos e carros, sinal evidente de que o interior do Mandhuy é local de desmanche, como bem observam os entrevistados.

Alguns usuários relacionam a precariedade da segurança no Mandhuy aos danos na cerca de alambrado, pois acreditam que isto tem contribuído para a entrada de "marginais" e "delinqüentes" no interior do parque. A cerca instalada para inibir o acesso de pessoas e animais domésticos, no interior do Mandhuy, não é suficiente, pois além da mesma poder ser facilmente danificada, como tem sido, a sua simples existência não irá impedir a invasão no interior do parque.

Os depoimentos sobre a entrada de fugitivos da 'cadeia', baseiam-se no fato da Delegacia de Polícia de Cianorte, localizar-se no Bairro Zona 7, a duas quadras da área do Mandhuy. A disposição espacial do Mandhuy, em parte encaixado entre os três bairros, limitando-se ao sul com uma rodovia (BR 323), contribui para essa ideia de insegurança.

Os toxicômanos no entorno e interior do Mandhuy é uma situação confirmada durante as observações de campo. Em conversas informais realizadas com os moradores de entorno, alguns relacionaram a instalação de bancos ao longo da pista de caminhada como um fator que favoreceu para a constante presença desses indivíduos na área do Mandhuy. No entanto, não podemos nos esquecer que o Mandhuy é um espaço público, logo é de todos, da criança, do idoso, da mulher, do negro, do branco, da prostituta, do homossexual, do usuário de drogas, do analfabeto, enfim de todos que contribuem direta e indiretamente com impostos para mantê-lo.

Como houve muitos apontamentos relacionando a cerca de alambrado com a segurança no Mandhuy, inseriu-se, nesse momento a análise da Questão 16 que busca saber se os usuários costumam ultrapassá-la, invadindo o seu 
interior, onde não é permitida a presença de público, de acordo com as normativas do zoneamento, expressas no Plano de Manejo de 2008 (Secretaria do Meio Ambiente de Cianorte, 2008). Dos entrevistados 96\% responderam que não ultrapassam a referida cerca, sendo que os $4 \%$ que afirmaram adentrar ao Mandhuy, ultrapassando a cerca, são todos homens, que justificaram sua entrada com os seguintes motivos: "buscar minhocas para pescar"; "olhar o seu interior"; "levar os cachorros para nadar no rio"; e "fazer alguma necessidade fisiológica". Este último motivo é até compreensível, pois no entorno do Mandhuy não há sanitários para uso do público que o utiliza.

No entanto, sabe-se que não é permitido às pessoas nem tão pouco a seus animais adentrar ao Mandhuy, pois ele constitui-se em uma Unidade de Conservação de Proteção Integral. Sua função primeira é proteger a natureza, "de nós os humanos", afinal "somos os vilões", e por isso este deve estar separado com cercas, para não correr o risco de ser depredado, e assim está. Sob certos aspectos, a criação de parques que objetivam garantir a preservação da natureza pode até acentuar a dicotomia entre natureza e comunidade que o rodeia.

Para verificar a grau de satisfação dos usuários para com o Módulo Mandhuy, perguntou-se - Questão 12 - do que estes mais gostam (Tabela 3) e do que menos gostam (Tabela 4) quando se utilizam dessa área. A questão foi formulada sem alternativas prontas para respostas, assim o respondente poderia indicar todos os elementos de que gosta ou não.

Analisando-se o teor das respostas dadas a essa questão, é possível agrupá-las em blocos, pois os elementos mencionados relacionam-se basicamente a algumas temáticas. Assim, no item equipamentos do parque estão inseridos: pista de caminhada, aparelhos de ginástica, campos de futebol, playgrounds etc. No bloco elementos naturais constam: vegetação e animais, a natureza, o verde, a grama, o cheiro da mata, os pássaros, entre outro. Os demais blocos apresentaram respostas semelhantes. 
Tabela 3 - Aspectos agradáveis no Módulo Mandhuy citados pelos usuários

\begin{tabular}{lc}
\hline Aspectos & № absoluto \\
\hline Equipamentos do Módulo Mandhuy & 19 \\
Elementos naturais & 100 \\
Localização & 3 \\
Parque/paisagem & 11 \\
Contato com as pessoas & 7 \\
Realizar atividades físicas & 4 \\
Sossego/tranqüilidade & 5 \\
Outros & 5
\end{tabular}

Nota: A somatória ultrapassa o oํ de usuários (100), devido à possibilidade do entrevistado poder apresentar vários elementos em sua resposta.

Fonte: Pesquisa realizada pela autora no Módulo Mandhuy, Cianorte 2010.

Os problemas com a segurança, a presença de lixo, a deficiência da iluminação, a carência de equipamentos para a prática de atividade física, e a manutenção desses equipamentos foram indicados como os elementos presentes no Mandhuy que causam desconforto em seus usuários. (Tabela 3).

Tabela 4 - Aspectos desagradáveis no Módulo Mandhuy citados pelos usuários

\begin{tabular}{lc}
\hline \hline Elementos relacionados a... & № absoluto \\
\hline Segurança & 31 \\
Convivência entre os usuários do parque & 36 \\
Infraestrutura e manutenção (lixo, iluminação, brinquedos & 40 \\
danificados etc). &
\end{tabular}

Nota: A somatória ultrapassa o oㅜ de usuários (100), devido à possibilidade do entrevistado poder apresentar vários elementos em sua resposta.

Fonte: Pesquisa realizada pela autora no Módulo Mandhuy, Cianorte 2010.

As características inerentes à vegetação, e que aguçam nossos sentidos, como "o cheiro da mata", "observar as árvores"; "o verde da mata, a natureza" foram os elementos lembrados com maior frequência.

Feiber (2004) ao estudar o caso do Passeio Público em Curitiba-Paraná, também observou a importância dada às árvores pela população entrevistada, sob as quais realizariam atividades de repouso e contemplação.

Diante da quantidade de problemas presentes nas respostas dadas pelos usuários, foram realizadas mais observações in loco, buscando averiguar alguns dos itens mencionados pelos entrevistados, o que possibilitou fazer 
alguns comentários. Os problemas relacionados ao lixo, segurança, presença de usuários de drogas, desmatamento, segurança dos brinquedos foram analisados anteriormente nesse estudo.

No bloco, 'convivência entre os usuários do parque', foi inserido o item uso indevido da pista de caminhada por outros sujeitos e foi o item mais evocado pelos respondentes. Alguns (pais e mães) praticam atividades físicas acompanhados pelos filhos menores com bicicletas ou em carrinhos de bebês, causando muito desconforto para os demais usuários, outros brincam com patins e skate, atitudes que tem desencadeado conflitos.

Algumas mulheres que levam seus bebês nos carrinhos não estão em atividades físicas, mas apenas utilizando a pista de caminhada para simplesmente se deslocarem, alegando que a pista é muito mais segura do que a rua. Nas ruas da área do Mandhuy, não há calçadas, somente grama, e a calçada do outro lado da rua são más conservadas, esburacada, entulhada de materiais de construção e em alguns pontos, inexiste. Isso explica em parte a presença de outros sujeitos na pista de caminhada.

Nas placas dispostas ao longo da pista de caminhada há a indicação de que seu uso é somente permitido para pedestres, sem companhia de animais domésticos ou com aparatos de locomoção (patins e skate).

Os atos de vandalismo com o patrimônio público, citados pelos usuários é uma realidade notada nas placas amassadas, nas lixeiras retorcidas e até arrancadas, nos bancos pichados, na cerca esburacada, nos brinquedos dos parques infantis danificados, até algumas árvores têm sido alvos de destruição. As ações dos vândalos representam grandes despesas de manutenção de um espaço como o do Mandhuy. Entretanto, nesse caso específico, os estragos poderiam ser maiores, tendo em vista a pouca segurança de que esta área dispõe.

Esse tipo de comportamento é muito comum em espaços públicos, em quase todo o mundo, Serpa (2007, p. 79) relata ações de vandalismo em alguns parques urbanos em Paris, afirmando que "o parque pode também se transformar em lugar de delitos e incivilidade, particularmente no período 
noturno". Assim, muitos gestores de espaços públicos, têm evocado o cercamento dessas áreas e as limitações de horário de uso.

Após análise das questões que desagradam os usuários do Mandhuy passou-se à Questão 13. Essa pergunta teve a intenção de levantar o grau de envolvimento da comunidade com essa área protegida. Mesmo considerando que o gestor - Secretaria Municipal do Meio Ambiente (SMMA) - é o responsável direto por todo o Parque Cinturão Verde, compreende-se que a participação do cidadão é indispensável para se manter uma área pública com todas as limitações que o Mandhuy apresenta. Dos entrevistados 75\% (Figura 4) afirmaram que esta tarefa é da população em geral e do poder público. Diante dos dados, tem-se então um paradoxo. Pois se é esse o entendimento da maioria dos entrevistados, um dos sujeitos não tem cumprido com sua parte.

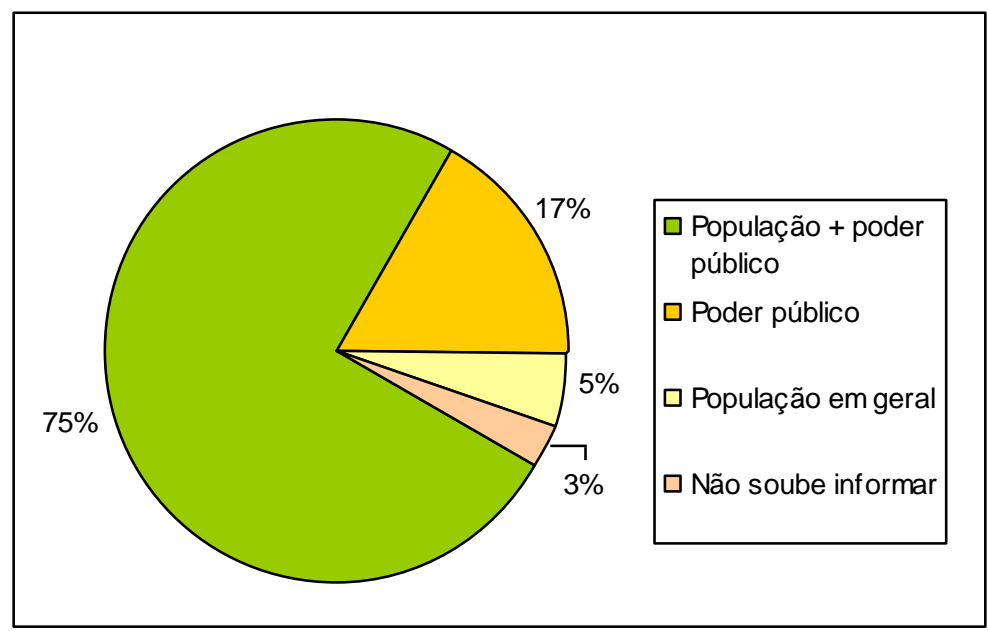

Figura 4: Responsabilidade pelos cuidados com o Módulo Mandhuy segundo os seus usuários

O gestor - SMMA - faz limpeza periódica no interior e entorno do Mandhuy do qual retira toneladas de lixo, apara a grama regularmente, realiza capina em todo entorno, reconstrói a cerca de alambrado, substitui as placas e as lixeiras danificadas, controla os incêndios, refloresta as áreas com vegetação mais degradada, entre outras ações. E a comunidade, que se relaciona com o Mandhuy, o que tem feito? Aqui está o paradoxo, praticamente todos os 
problemas listados são gerados pelos membros da comunidade da área do Mandhuy (usuários e moradores), independente da proximidade e do grau de contato com a mesma.

Considerou-se relevante inserir nesse momento os resultados da análise das respostas dadas à Questão 14, que indicou como os entrevistados têm interagido nesse aspecto com o Parque, já que apresentaram nas respostas dadas à questão 12 diversos elementos que os desagradam profundamente $\mathrm{e}$ também porque a maioria afirmou na questão 13 que por isso são corresponsáveis pela manutenção do Parque.

Quanto aos cuidados que os usuários afirmam dispensar ao Mandhuy, notase que os principais problemas são alvos desses cuidados, entretanto continuam a representar objeto de suas reclamações. (Tabela 5)

A problemática do lixo novamente vem à tona estando presente na maior parte das respostas, em algumas vezes atrelada a outros cuidados que poderiam ser dirigidos ao Mandhuy. Como denunciar aos órgãos responsáveis ações vandálicas causadas a área, estão contribuindo de forma positiva com o Mandhuy. Há ainda outros que apostam que podem cuidar do Mandhuy através da conscientização e educação das pessoas.

Tabela 5 - Cuidados para com o Mandhuy, apresentados pelos usuários

\begin{tabular}{lc}
\hline \hline Cuidados & № absoluto \\
\hline Limpeza (lixo) & 60 \\
Fiscalizar/denunciar & 23 \\
Preservar os equipamentos & 23 \\
Meio ambiente (não poluir, desmatar etc). & 12 \\
Não soube informar/não pode fazer nada & 2 \\
Não trazer animais ao parque & 1 \\
Pagar os impostos & 1 \\
\hline \hline
\end{tabular}

Nota: A somatória ultrapassa o ํo de usuários (100), devido à possibilidade do entrevistado poder apresentar vários elementos em sua resposta.

Fonte: Pesquisa realizada pela autora no Módulo Mandhuy, Cianorte 2010.

Menos de $10 \%$ dos entrevistados afirmaram "não poder fazer nada pelo Mandhuy". Nesse grupo houve aqueles que lembraram que já pagam impostos para que o poder público cuide desse espaço. O ICMS Ecológico imposto que 
o Parque Municipal Cinturão Verde recebe, também foi lembrado como recurso para financiar os cuidados com o Parque.

Avaliando as respostas dadas, é possível inferir algumas leituras. Primeiro os usuários demonstraram claramente como poderiam participar dos cuidados com o Mandhuy. Mas, se assim o fazem, como se explica a situação em que o parque se encontra? Segundo, se estes têm o hábito de denunciar os problemas percebidos, porque não têm ocorrido mudanças?

Questionou-se também os usuários (Questão 18) sobre o que estes gostariam que tivesse no Mandhuy. As sugestões foram inúmeras. Na Tabela 6 estão presentes os itens mais solicitados.

\begin{tabular}{lc} 
Tabela 6 - Componentes ausentes ou que precisam melhorar no Módulo Mandhuy \\
\hline \hline Componentes & № absoluto \\
\hline Equipamentos (infraestrutura) & 34 \\
Equipamentos (para atividades físicas) & 29 \\
Segurança & 25 \\
Estrutura interna (trilhas, bosque, lago etc). & 11 \\
Animais silvestres (zoológico) & 5 \\
Vegetação & 5 \\
Manutenção (coleta de lixo) & 3 \\
Outros/Nada/não respondeu & 10
\end{tabular}

Nota: A somatória ultrapassa o $\mathrm{n}^{\circ}$ de usuários (100), devido à possibilidade do entrevistado poder apresentar vários elementos em sua resposta.

Fonte: Pesquisa realizada pela autora no Módulo Mandhuy, Cianorte 2010.

Os equipamentos para infraestrutura do parque que os usuários gostariam que fossem inseridos ou melhorados são: água potável, sanitários, iluminação, lixeiras, ciclovia, placas de sinalização, bancos, churrasqueiras, mesas próximas às árvores, cercas para os playgrounds, entre outros.

Alguns dos itens, acima mencionados, simplesmente não existem na infraestrutura do parque, como é o caso dos sanitários e água. Outros como lixeiras, bancos e placas de sinalização constam da infraestrutura, entretanto muitos já foram destruídos. As churrasqueiras, provavelmente, não serão inseridas na área do entorno do Mandhuy, por representarem possibilidade de incêndios. 
A solicitação para a construção de uma ciclovia é uma das principais necessidades dos usuários. Essa medida poderia amenizar os conflitos entre os diferentes grupos que utilizam a pista de caminhada.

Os equipamentos para prática de atividades físicas foram o segundo bloco de itens mais citados pelos respondentes. Neste bloco estão as ATI's ${ }^{2}$, mais pontos com barras para aquecimento antes das atividades físicas, aumento da pista de caminhada, atingindo o entorno do bairro Zona 7, conectando a pista das proximidades do Conjunto Moradias Marselha, instalar mais brinquedos nos parques infantis, quadra para vôlei, campos de futebol, entre outros.

Esses pedidos, ou até desejos expressos nas respostas dos entrevistados, denotam a necessidade de melhorar e implementar a infraestrutura existente no parque, a exemplo da instalação de uma academia para a terceira idade ATI's. Algumas ATl's já estão presentes em outros módulos do Parque Cinturão Verde e em outros locais públicos da cidade.

O uso do interior do parque pelos usuários foi expresso quando estes responderam que gostariam que fossem implantadas trilhas para poderem circular em seu interior. No Plano de Manejo, implantado em 1994, definiramse no zoneamento (área bem menor que a atual) os setores em que o público poderia ter acesso, em trilhas interpretativas, com função recreativa e de educação ambiental. Passados quinze anos, essas trilhas nunca saíram do papel.

Essas respostas também demonstram que muitos dos usuários ressentemse de espaços mais aprimorados para o lazer não pago e gostariam que 0 Mandhuy se assemelhasse a parques de outras cidades, que possuem zoológicos, trilhas, lagos, entre outros aparatos de lazer.

$O$ bloco de pedidos mais curioso é o relacionado à vegetação. Alguns entrevistados gostariam que tivesse mais árvores no Parque. A SMMA de Cianorte vem plantando árvores ao longo das ruas do entorno do Mandhuy o que futuramente irá melhorar a produção de sombras na área do relvado. $O$ problema é que as mudas vêm encontrando muitas dificuldades para se desenvolverem, inclusive algumas já foram arrancadas, outras quebradas, e

\footnotetext{
${ }^{2}$ Em dezembro de 2009 foi instalada uma ATI no entorno do Módulo Mandhuy
} 
algumas tiveram melhor sorte, foram adotadas pelo morador da frente, passando a receber todos os cuidados necessários para o seu crescimento.

A Questão 8 busca saber o quanto de tempo os usuários do Mandhuy dispensam para atividades consideradas lazer, devido à constante retomada da temática pelos entrevistados que clamam pela disponibilidade de espaços que atendam a suas necessidades recreativas. O resultado obtido revelou que $69 \%$ dos usuários dispensam tempo reduzido, menos de 8 horas semanais ao lazer, o que resultaria em pouco mais de 1 hora por dia e, em alguns casos, mais extremos, a resposta foi de 1 hora por semana.

A maioria dos usuários do Mandhuy (76\%) exerce algum tipo de atividade econômica, basicamente nas categorias: empregados e autônomos, além daqueles que se identificaram como do lar, pois desenvolvem atividades informais resultando em algum tipo de remuneração. Nessa perspectiva, questionamos os usuários, sobre a quantidade de horas diária de trabalho (Figura 5).

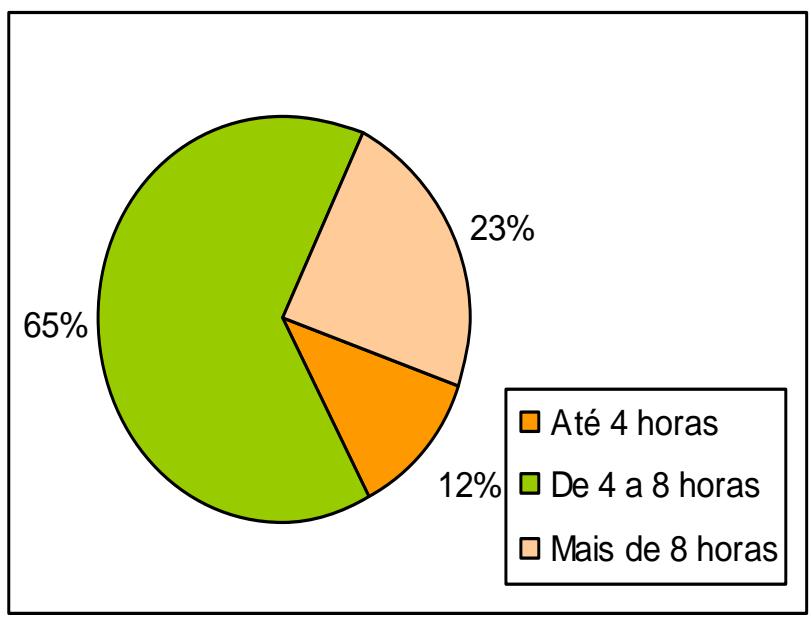

Figura 5: Horas diárias de trabalho dos usuários do Módulo Mandhuy

Assim, identificou-se que $65 \%$ dos entrevistados, que realizam atividades remuneradas, o fazem em jornadas de 8 horas diárias de trabalho, somando-se 44 horas semanais, como prevê as leis trabalhistas vigentes no país.

Nas grandes cidades o trabalhador consome grande parte do seu tempo no transporte entre sua residência e seu local de trabalho, em Cianorte essa 
situação esta muito distante de ser vivenciada pelos nossos trabalhadores, para qualquer direção que se vá utiliza-se apenas alguns minutos. Então o que é feito com o tempo livre?

As mulheres, mesmo não apresentando respostas muito diferentes das dos homens, foi o grupo que mais reclamou sobre o pouco tempo que podem destinar para o lazer. Algumas entrevistadas afirmaram não dispor de nenhuma hora por semana para o lazer. Alegam que, além do trabalho realizado fora de casa, ainda são elas as únicas responsáveis pelas tarefas domésticas e dos cuidados com filhos (escola, saúde etc), não sobrando tempo algum para atividades de lazer, afirmam que "não param nunca de trabalhar" e que, só o fazem quando vêm ao Parque para caminhar.

Alguns trabalhadores executam jornadas diárias de trabalho superior a 10 horas. Estas situações estão atreladas às atividades econômicas informais, realizadas em ambientes domésticos, geralmente relacionadas à base econômica de Cianorte, que tem no vestuário a sua principal atividade econômica que gera muitos postos de trabalho formais, mas também produz uma legião de trabalhadores na informalidade. A fragmentação de horas diárias de trabalho (1h, 3h, 4h.) corresponde com o trabalho informal.

Em levantamento realizado em 2007, para elaboração do Plano de Manejo, pelo Observatório das Metrópoles - Núcleo Região Metropolitana de Maringá, que buscou identificar junto aos usuários do Mandhuy (denominado Parque 1 na referida pesquisa) as principais atividades de lazer realizadas por esses sujeitos. Destacaram-se: pescar, ir ao sítio, fazer churrasco, jogar bola, ir ao clube, assistir a TV, cuidar da casa, cozinhar, ir a igreja, descansar em casa (..). Não aparecem nessa relação quase nenhuma atividade que esteja relacionada ao espaço do parque, nem mesmo a prática de caminhadas.

Como não é objetivo desse estudo aprofundar na temática do lazer, apenas de relacionar tempo destinado ao lazer pelo trabalhador com espaços públicos adequados e acessíveis, que de acordo com os estudos de De Angelis (2000, p. 228) 'Esses espaços devem considerar a 'massa' populacional que deles fará uso; um contingente cada vez mais exigente e crítico, cioso de seus direitos e muitíssimo mais politizado e organizado que no passado". 
Nas respostas dadas à Questão 18, nota-se o desejo de muitos usuários entrevistados, de utilizar o interior do Módulo Mandhuy para possíveis atividades de lazer.

Nessa perspectiva, a parir da análise da Questão 17, que teve como objetivo captar o grau de conhecimento do usuário em relação à finalidade da existência dessa área percebe-se através das respostas dadas visões bem distintas sobre a finalidade do Mandhuy. Mesmo assim, foi possível identificar e agrupar em três leituras dos usuários que buscam explicar a finalidade desse espaço protegido (Tabela 7).

Tabela 7 - Opinião dos frequentadores do Módulo Mandhuy, quanto a sua finalidade.

Serve para: $\%$

Preservar a natureza

39

Atender as necessidades da população 26

Preservar a natureza e, ao mesmo tempo, usufruto da população. 10

Não sabe

Outros

10

Fonte: Pesquisa realizada pela autora no Módulo Mandhuy, Cianorte 2010.

Um grupo de entrevistados, representando $26 \%$ dos usuários, entende que a finalidade do Mandhuy é puramente utilitarista, demonstrando a supremacia do "homem" sobre toda a natureza, visão considerada antropocêntrica, onde o meio natural em que se vive lhe é apenas útil.

Para esse grupo de usuários a manutenção de áreas naturais a exemplo do Mandhuy, em áreas urbanas, justifica-se pela necessidade que a sociedade tem por áreas de lazer e consequente bem estar. Milano (2002, p. 204) discorda veemente dessa postura, afirmando que, "[...] a proteção da natureza não se faz apenas para garantir a nossa própria sobrevivência, tampouco com o objetivo principal de lucrar com ela: a proteção da natureza é antes de tudo uma necessidade moral essencial [...] é parte de nossa identidade como habitantes da Terra".

Segue afirmando categoricamente que,

As unidades de conservação existem para proteger a natureza, na sua maior amplitude possível, da sistemática agressão humana, seja esta decorrente de processos tecnológicos, econômicos, culturais e políticos modernos ou atuais, ou decorrente de processos arcaicos ou tradicionais: ainda que para beneficio da própria humanidade. 
Também as unidades de conservação não foram pensadas e nem foram criadas para promover o desenvolvimento, ainda que, como conseqüências de sua existência com bom manejo, possam propiciálo. (MILANO, 2002, p. 206).

Uma segunda visão expressa por 39\% dos entrevistados foi a naturalista, que combina com a visão de Milano (op cit), pois em suas respostas deu-se ênfase aos componentes bióticos e abióticos do Parque, excluindo-se por completo o elemento humano.

Entretanto, excluir o elemento humano, na área urbana de um espaço natural, é uma tarefa que beira ao impossível, sem contar que não faz nenhum sentido a manutenção de um parque onde a comunidade de seu entorno e das proximidades não possam ter acesso.

Para Cattaneo (2004, p. 65), o modelo de unidades de conservação que fazemos uso, "tende a dicotomizar homem e natureza, hierarquizando as relações e classificando, de forma estanque, os elementos humanos e naturais".

Essa concepção norteia o plano de manejo que estabelece o zoneamento para o PCVC, de acordo com este, no Módulo Mandhuy, não há nenhuma área que pode ser utilizada, por enquanto, para atividades recreativas como desejam muitos entrevistados, salvo o seu entorno. Assim, a relação da comunidade deve se adaptar aos conceitos prontos, identificados por Cattaneo (2004) como os grandes responsáveis pela geração de conflitos entre comunidade e área protegida, mas poderiam ser amenizados caso os conceitos fossem adaptados à realidade do lugar onde se insere uma unidade de conservação.

Um terceiro grupo, pouco expressivo, representando $10 \%$ dos usuários entrevistados, demonstrou em suas respostas a incorporação dos aspectos socioculturais e a dimensão ecológica, combinando preservação e uso do espaço pela comunidade.

A visão acima corresponde à de natureza integradora - representando o conjunto de todas as coisas, incluindo sociedade e suas transformações culturais. No entanto, a tentativa de reaproximação homem e natureza 
Constitui-se num dos paradigmas que segundo Brito (2005, p. 28), "dificilmente será superado".

Dos entrevistados, 15\% afirmaram não saber para que serve o Mandhuy, ou seja, a razão da sua existência. Essa falta de clareza por parte da comunidade, quanto à finalidade desta área protegida, resulta no conflito de interesse relativo à sua utilização, como já ficou explicitado em algumas questões ora já analisadas.

Praticamente todas as respostas atribuídas a esse questionamento, indicaram-nos que os usuários entrevistados desconhecem a razão de fato da existência do Mandhuy enquanto área natural protegida e suas limitações de uso estabelecidas pelo Plano de Manejo.

Sobre essa questão a Secretaria do Meio Ambiente de Cianorte (2008, p. 225-226) faz a seguinte observação:

\begin{abstract}
Grande parte dos entrevistados percebe o potencial de uso público do parque, identificando seus principais atrativos naturais e culturais, expressos nos sentimentos topofílicos, bem como, dos problemas mais evidentes que hoje ameaçam a área. Contudo, existe ainda uma carência do conhecimento cientifico da área e dos aspectos legais por parte dos entrevistados, fato evidente nas falas e expectativas expressas, que resultam quase sempre em ações conflituosas com a administração do parque.
\end{abstract}

A falta de debate com a população que deve preceder à criação desses espaços, explica em parte, essa situação. Muitas vezes os debates com a comunidade ocorrem apenas para legitimar o que já fora previamente decidido. Nessa perspectiva, não é possível à comunidade alterar ou influenciar as funções ou finalidades que esse tipo de espaço virá a ter.

Finalizamos nossa investigação junto aos usuários perguntando-lhes se acham que essa área deve ser mantida (Questão 19). Noventa e nove por cento dos entrevistados responderam que se deve manter o Módulo Mandhuy. Frente ao expressivo índice, desdobramos a pergunta para estes justificarem sua resposta. Por que o Mandhuy deve ser mantido?

As justificativas dadas foram bastante variadas. Porém, percebemos que elas partiam de três leituras, coincidindo com a postura emitida na questão 17, em que os entrevistados se dividiram em três distintos grupos, exprimindo três 
leituras sobre o Mandhuy - antrópica, ecológica e integradora - conciliando sociedade e natureza - (Tabela 8).

A visão antropocêntrica é expressa por $47 \%$ dos usuários que defendem a manutenção do Mandhuy, sob argumento de que este lhes é apenas útil e por isso deve ser mantido. Ao manifestar essa opinião, o usuário demonstra uma atitude utilitarista e individualista em relação à natureza, de que esta somente existe para suprir suas necessidades.

Tabela 8 - Opinião dos frequentadores do Módulo Mandhuy quanto a preservação

\begin{tabular}{lc}
\hline \hline Justificativas: & № absoluto \\
\hline Atender as necessidades da população & 47 \\
Proteger a natureza & 31 \\
Proteger a natureza e, ao mesmo tempo, para usufruto da população. & 6 \\
Outras finalidades & 9 \\
Não soube informar & 6 \\
\hline \hline
\end{tabular}

Fonte: Pesquisa realizada pela autora no Módulo Mandhuy, Cianorte 2010.

Outro grupo representando $31 \%$ dos entrevistados justifica a manutenção do Mandhuy por razões puramente ecológicas. Outros entrevistados, representando 6\% dos usuários, responderam que a manutenção do Mandhuy se justifica por ser relevante tanto para a preservação como para a comunidade.

Alguns entrevistados, 6\%, não emitiram justificativas para a manutenção dessa área. Outros $9 \%$ apresentaram justificativa sem sentido, e o entrevistado que defende a ideia da não manutenção do Módulo Mandhuy, alega que esse "Só serve para esconder bandido quando foge da delegacia e se esconde na mata". Esse usuário relaciona o Parque a fatos negativos.

A questão 15, que busca saber, junto aos usuários, se esses observaram mudanças na paisagem, especificamente no conteúdo vegetação e também na presença de animais. Cinquenta e seis por cento dos entrevistados informaram que há mais vegetação agora do que no passado; $18 \%$ que há menos vegetação. Um dos entrevistados assegurou que "a mata encolheu, a ponto de ser possível avistar as casas do outro lado (casas do bairro Zona 7)"; e $26 \%$ não se posicionaram, alegando que não observaram mudanças significativas nesse sentido. No tocante aos animais, 55\% dos entrevistados responderam 
que no Mandhuy há hoje bem menos animais, enquanto que $26 \%$ acreditam que na área do Mandhuy, há hoje mais animais, inclusive mais aves.

Aqui é mister fazer algumas ressalvas. Primeiro que a maioria dos usuários entrevistados (78\%) reside na Zona 3, e a visão que se tem do Mandhuy, a partir desse bairro, é de muita vegetação. Logo, se somarmos $56 \%+26 \%$ (usuários que responderam que há mais vegetação e os que responderam que não observaram mudanças) tem-se $82 \%$ dos entrevistados, número semelhante ao dos moradores da Zona 3 que frequentam o Mandhuy. Segundo, quando se observa o Mandhuy, a partir dos dois outros bairros do seu entorno, a resposta obrigatoriamente será o oposto, pois a partir da Zona 7 e do Conjunto Moradia Marselha o que se vê é uma vasta capoeira constituída de capim colonião, samambaias e alguns arbustos, pontilhadas por árvores mortas pelos incêndios.

\section{CONCLUSÃO}

No Módulo Mandhuy, assim como em todo PCVC a única parte da sua área em que é permitido o acesso da população é seu entorno, funcionado como um parque urbano, devendo então estar adequadamente organizado para esse fim, a qualquer momento do dia.

Vários depoimentos indicaram ligeiro conflito em relação ao uso do Módulo Mandhuy, muito comum quando o assunto é unidade de conservação presente em espaços urbanos que, por determinação do SNUC, mesmo constituindo-se em locais fundamentais para a visitação, o lazer e a recreação das comunidades vizinhas, são impostas muitas restrições à presença humana. Restringir o uso e acesso das populações em áreas naturais protegidas, sem que estes compreendam as razões para tal, contribui para sua degradação.

Os cidadãos almejam por espaços públicos estruturados com equipamentos, constituindo-se em atrativos de lazer e recreação, sem restrição. Esse tipo de espaço tem sido constantemente ressaltado como elemento que pode contribuir significativamente para a melhoria da qualidade de vida nas cidades, 
mas fica apenas nas propostas dos políticos e administradores das políticas urbanas não atendendo à vontade das populações.

É evidente a falta de pessoal com capacitação para envolver melhor a comunidade a respeito da importância do Módulo Mandhuy tanto para os moradores de entorno como para a cidade. Isso seria o cumprimento de uma das funções dos Parques, que é também propiciar condições para a educação ambiental. Ação por parte do gestor com objetivo de fomentar a consciência ambiental que requer trabalho efetivo junto à comunidade, pois a manutenção de espaços preservados que possam ser utilizados pela população, depende do envolvimento da comunidade.

\section{REFERENCIAS}

BALLAROTTI, L. Análise das Condições ambientais do Parque Arthur Thomas e sua importância para a população de Londrina - PR. Dissertação (Mestrado em Geociências) - Universidade Estadual de Londrina, Londrina. 2005.

BIONDE, D.; MÓRMUL, M. L. Parques Urbanos de Curitiba/PR - qual a Preferência de seus usuários? IN: VII ENPEA - Encontro Nacional de Paisagismo em Escolas de Arquitetura e Urbanismo no Brasil. Belo Horizonte. 2004. Disponível em: shttp://www.usp.br/fau/> . Acesso em 04 ago. 2008.

BRASIL. Ministério do Meio Ambiente. Sistema Nacional de Unidades de Conservação da Natureza. SNUC - Lei no 9.985, de 18 de julho de 2000. Brasília: MMA, 2000.

BRITO, A. G. O Cerco à natureza: o simbolismo e as conflitantes formas de apropriação presentes no Morro Anhangava - Quatro Barras - Paraná. Monografia de conclusão de curso. Universidade Federal do Paraná, Curitiba, 2005.

CATTANEO, D. Identidade Territorial em Unidades de Conservação: ponto de apoio para uma análise epistemológica da questão ambiental. Dissertação (Mestrado em Geografia). Universidade Federal do Rio Grande do Sul, Porto Alegre, 2004.

DE ANGELIS, B.L.D. A praça no contexto das cidades - o caso de Maringá/PR. Tese (Doutorado em Geografia). Universidade de São Paulo - USP. São Paulo. 2000.

DELGADO-MENDEZ, Jesus Manuel. Proteção de Áreas Naturais e Desenvolvimento Social: Percepções de um conflito na gestão de Unidades de Conservação de Proteção Integral. 204 f. Tese de Doutorado. Universidade de 
São Paulo - Escola Superior de Agricultura "Luiz de Quieroz". Piracicaba. São Paulo. 2008.

FEIBER, S. D. Áreas Verdes Urbanas Imagem e Uso - o caso do Passeio Público de Curitiba - PR. Curitiba. RA’E GA. n 8, p. 93-105, 2004. Disponível em: <http://ojs.c3sl.ufpr.br/ojs2/index.php/raega/article/s. Acesso 22 de fev. 2009.

FERREIRA, A. Efeitos Positivos gerados pelos parques urbanos - O caso do Passeio Público do Rio de Janeiro. Dissertação (Mestrado em Ciência Ambiental) Universidade Federal Fluminense, Rio de Janeiro, 2005.

GUZZO, P. Áreas Verdes Urbanas. Programas Pró-ciências - áreas verdes. $2004 . \quad$ p.2. Disponível em: $\leq$ http://educar.sc.usp.br/biologia/prociencias/areasverdes.html>. Acesso em 22 mar. 2009.

HARDT, L. P. A.; HARDT, C. Reflexões sobre políticas ambientais e urbanas no âmbito do planejamento e gestão de unidades de conservação. p. 111 -115. In. ORTH, D; DEBETIR, E. (orgs). Unidades de conservação - gestão e conflitos. Florianópolis: Insular, 2007.

LOBODA, C. R. Estudo das Áreas Verdes urbanas de Guarapuava - PR. Dissertação (Mestrado em Geografia). Universidade Estadual de Maringá. Maringá, 2003.

LOBODA, C. R; DE ANGELIS, B. L. D. Áreas Verdes Públicas: Conceitos, Usos e Funções. Ambiência, Guarapuava. v.1, n. 1 p. 125-139, 2005. Disponível em: http://www.unicentro.br/editora/revistas. Acesso 01 jan. 2008.

MILANO, M. S. (org.) - Unidades de conservação: atualidades e tendências. Curitiba. Fundação o Boticário de Proteção à Natureza, 2002.

OLIVEIRA, Ivone Adelina. Gestão de conflitos em parques: estudo de caso do entorno nordeste do Parque Estadual da Serra do Tabuleiro. 269 f. Tese. (Doutorado em Engenharia da Produção) - Programa de Pós-Graduação em Engenharia da Produção, UFSC, Florianópolis, 2005.

OLIVEIRA, T. M. V. Amostragem não Probabilística: Adequação de Situações para uso e Limitações de amostras por Conveniência, Julgamento e Quotas. Revista Administração On Line. São Paulo. v.2 no 3, jul/ago/set. 2001. Disponível em: <http://www ./fecap.br/adm online/art23/tania2.htm.>. Acesso 26 fev. 2009.

PAIVA, H. N; GONÇALVES, W. Florestas Urbanas: planejamento para melhoria da qualidade de vida. Viçosa. Aprenda Fácil, 2002.

PIMENTEL, Douglas de Souza. Os "Parques de papel" e o papel social dos parques. 251 f.Tese de Doutorado. Universidades de São Paulo - Escola Superior de Agricultura "Luiz de Queiroz". São Paulo. 2008. 
PORFIRIO et al. Formas de Interação de três bairros periféricos com o Parque Municipal das Mangabeiras, Belo Horizonte/MG. Árvore, Viçosa-MG, v.30, n.6, p.1033-1038, 2006. Disponível: http://www.scielo.br/scielo.php?. Acesso 9 de julho de 2011.

RIBEIRO, W. C. Entre Prometeu e Pandora - sociedade e natureza no inicio do século XXI. P. 323 - 334. . In: CARLOS, A. F. A.; LEMOS, A. I. G. (orgs). Dilemas Urbanos: novas abordagens sobre a cidade. São Paulo. Contexto. 2003.

ROCHA, S. A. A valorização da paisagem natural protegida em área urbana: Parque Municipal do Finder, Joinville (SC), Dissertação (Mestrado em Geografia), Universidade Federal de Santa Catarina, Florianópolis, 2006.

SCARLATO, F. C; PONTIN, J. I. A. O ambiente urbano. São Paulo: Atual, 1999.

Secretaria Municipal do Meio Ambiente de Cianorte. Plano de Manejo. Cianorte, 1994.

Plano de Manejo. Cianorte, 2008.

SERPA, A. O Espaço Público na Cidade Contemporânea. São Paulo: Contexto, 2007.

SILVA, M.J.L; EGLER, I. O Estudo da percepção em espaços urbanos preservados. IN: I Encontro - ANPPAS - Associação Nacional de Pós Graduação e Pesquisa em Ambiente e Sociedade. Indaiatuba. 2002. Disponível em: www.anappas.org.br/encontro anual. Acesso em 12 de julho 2011.

SPÓSITO, M. E. B. O embate entre as questões ambientais e sociais no urbano. p. 295 - 298. IN: CARLOS, A. F. A.; LEMOS, A. I. G. (orgs). Dilemas Urbanos: novas abordagens sobre a cidade. São Paulo: Contexto, 2003. 